\title{
PENDOKUMENTASIAN APLIKASI RAGAM HIAS BUDAYA BALI, SEBAGAI UPAYA KONSERVASI BUDAYA BANGSA KHUSUSNYA PADA PERANCANGAN INTERIOR
}

\author{
Grace Hartanti; Amarena Nediari \\ Interior Design Department, School of Design, BINUS University \\ Jln. K.H. Syahdan No. 9, Palmerah, Jakarta Barat 11480 \\ gracehartanti@yahoo.com; amarenanediari@yahoo.co.id
}

\begin{abstract}
Various ornament of Indonesian people comes from the ethnic groups from all over the archipelago. As a tangible cultural ornament has a specific purpose and it does not change throughout the ages. Bali is one of the ethnic group in archipelago that has beautiful decorative art and one of the most popular tourism destination in Indonesia. Bali's ornament generally seen as decorative carving on the column, window or even in door. The beauty of Bali is not only as an inspiration for their colors and sculpture but also the variety of forms that have been simplified in the ornament. Moreover, floral \& fauna forms are easy to apply as an interior element in modern buildings. Generally the value of these ornament has a specific purpose related to the cultural and social custom in Bali people. So that the application need to consider more about the purpose of the symbol of the ornament.
\end{abstract}

Keywords: Bali Ornament, Bali, interior element

\begin{abstract}
ABSTRAK
Kekayaan ragam hias yang dimiliki oleh Bangsa Indonesia, berasal dari berbagai suku di seluruh pelosok Nusantara. Sebagai hasil dari budaya tangible (berwujud) ragam hias umumnya mempunyai makna tertentu yang pasti dan tidak berubah pengertiannya sepanjang zaman. Bali merupakan salah satu suku di Nusantara yang kaya akan seni ragam hias yang menarik dan merupakan salah satu destinasi pariwisata paling populer di Indonesia. Ragam hias Bali umumnya berupa hasil ukiran pada papan kayu yang dapat dijumpai pada tiang, jendela ataupun pintu. Keindahan alam di Bali tidak hanya sebagai sumber inspirasi dari warna ukiran namun juga berbagai bentuk yang telah disederhanakan pada ragam hiasnya. Selain itu bentuk ornamen yang mengambil motif floral dan fauna sangat mudah diaplikasikan sebagai elemen interior pada bangunanbangunan modern. Umumnya makna yang terkandung dari ragam hias ini mempunyai arti yang erat kaitannya dengan budaya dan tatanan adat istiadat masyarakat Bali. Sehingga dalam penerapannya perlu diperhatikan lebih jauh tentang makna simbol dari ragam hias tersebut.
\end{abstract}

Kata kunci: Ragam hias Bali, Bali, elemen interior 


\section{PENDAHULUAN}

Indonesia memiliki keanekaragaman budaya yang berasal dari berbagai suku bangsa yang tersebar di seluruh pelosok tanah air. Sabang hingga Merauke memberikan ragam warna budaya, bahasa serta adat istiadat yang berbeda bagi masyarakat Indonesia, walapun begitu nuansa ketimuran tetap menjadi jiwa dari budaya Indonesia. Upaya pelestarian budaya Indonesia perlu dilakukan untuk menjaga identitas bangsa, menjaga kesatuan rakyat Indonesia serta mempertahankan nilai-nilai luhur perjuangan bangsa Indonesia dalam meraih kemerdekaannya. Sehingga keanekaragaman budaya Indonesia tetap menjadi kebanggaan generasi penerus di masa yang akan datang.

Beribu-ribu pulau di Indonesia yang memberikan warna budaya Nusantara hanya ada satu pulau yang namanya sudah berkumandang di seluruh dunia, yaitu pulau Bali. Sebagai salah satu destinasi utama wisata di dunia, pulau Bali yang juga dikenal dengan Pulau Dewata memiliki keindahan alam serta ritual budaya yang menarik perhatian wisatawan baik mancanegara maupun domestik. Penduduk pulau Bali yang berjumlah sekitar empat juta jiwa ini mayoritas adalah pemeluk agama Hindu. Masyarakat Bali memiliki beragam tradisi yang menjadi daya tarik bagi para wisatawan. Ritual yang sudah menjadi bagian dari kehidupan sehari-hari menjadikan budaya Bali terus bertahan sampai dengan hari ini. Keterampilan para pengrajin kayu di Bali menghasilkan ukiranukiran yang indah dan banyak diaplikasikan pada bangunan-bangunan Bali, diantaranya adalah pada tempat ibadah dan rumah-rumah tradisional Bali. Pada umumnya bangunan atau arsitektur tradisional daerah Bali selalu dipenuhi hiasan, berupa ukiran, peralatan serta pemberian warna. Ragam hias tersebut mengandung arti tertentu sebagai ungkapan keindahan simbol-simbol dan penyampaian komunikasi. Bentuk-bentuk ragam hias dari jenis flora fauna juga berfungsi sebagai simbol-simbol ritual yang ditampilkan dalam patung.

Upaya pemerintah Indonesia dalam melestarikan serta mengembangkan tradisi kebudayaan daerah tertuang pada TAP MPR RI no IV/MPR/1999 yang membahas masalah sosial budaya Indonesia, yaitu sebagai salah satu warisan budaya yang patut dilestarikan, ragam hias tradisional adalah aset yang sangat potensial untuk dikembangkan. Ragam hias Nusantara terdapat dalam bentukbentuk dasar yang sama namun mengalami berbagai perubahan dan variasi yang khas untuk setiap daerah. Dalam karya kerajian atau seni Nusantara sering kali terdapat makna spiritual yang dituangkan dalam aneka model ragam hias.

Ragam hias tradisional dapat diaplikasikan sebagai unsur dekoratif maupun konstruktif dalam dunia desain interior. Penerapan ragam hias pada interior seringkali mengalami perubahan dan pengembangan baik dari segi bentuk, pola, material, teknik pembuatan serta warna yang berbeda dengan ragam hias aslinya. Dalam perkembangannya aplikasi ragam hias tradisional ini harus tetap dipertahankan makna tradisional yang terkandung di dalamnya. Hal ini untuk menghindari penyalahgunaan terhadap makna ragam hias yang tidak sesuai penempatannya, sehingga memiliki arti yang berbeda dan salah. Penelitian terhadap ragam hias ukiran Bali ini dilakukan dengan pendokumentasian aplikasi ragam hias tradisional Bali yang diterapkan pada fasilitas publik yaitu restoran.

\section{HASIL DAN PEMBAHASAN}

\section{Provinsi Bali}

Provinsi Bali meliputi $0.3 \%$ dari seluruh daratan wilayah Negara Kesatuan Republik Indonesia.Luas wilayah provinsi Bali adalah $5.636,66 \mathrm{~km}^{2}$, dan terletak diantara Jawa dan Lombok, 
pulau dengan jumlah penduduk sejumlah 4 juta jiwa lebih ini mayoritas penduduknya menganut agama Hindu (Picard, 2006). Selain dari sektor pariwisata, penduduk Bali juga hidup dari pertanian serta perikanan. Bali juga dikenal dengan karya seninya yang berupa lukisan serta ukirannya, sehingga penduduknya banyak yang menjadi seniman.Pulau Bali terletak di $8^{\circ} 25^{\prime} 23^{\prime \prime}$ Lintang Selatan dan $115^{\circ} 14^{\prime} 55^{\prime \prime}$ Bujur Timur sehingga beriklim tropis seperti seluruh bagian wilayah Indonesia lainnya.Wilayah pulau Bali berbatasan dengan Provinsi Jawa Timur (bagian Barat), Provinsi Nusa Tenggara Barat (bagian Timur), Samudra Indonesia (bagian Selatan) dan Laut Bali (bagian Utara).Secara administratif Provinsi Bali terbagi atas 9 kabupaten, 55 kecamatan dan 701 kelurahan.

Bahasa yang digunakan oleh penduduk Bali adalah bahasa Indonesia, namun umumnya penduduk Bali yang bekerja di sektor pariwisata menguasai bahasa Inggris sebagai bahasa asing pertama, sebagian dari mereka juga memahami bahasa Jepang. Hal ini dipengaruhi oleh kebutuhan yang besar dari industri pariwisata karena para wisatawan mancanegara yang datang ke pulau Bali banyak yang berasal dari Australia, Belanda, Jerman dan Jepang.Bahasa Bali juga masih banyak digunakan oleh penduduk setempat untuk berkomunikasi.Secara tradisi, penggunaan berbagai dialek bahasa Bali ditentukan berdasarkan system catur warna dalam agama Hindu Dharma.

Di tengah-tengah pulau Bali terbentang pengunungan yang memanjang dari arah barat ke timur. Pada bagian utara pulau Bali merupakan daeran pegunungan dan gunung Agung merupakan gunung berapi tertinggi di Bali, sementara bagian selatan pulau Bali adalah dataran rendah yang dialiri dengan sungai-sungai. Provinsi Bali memiliki 4 buah danau yang berlokasi di daerah pegunungan, yaitu danau Bedugul, Buyan, Tamblingan dan Batur.Keindahan alam di pulau Bali inilah yang menjadikan Bali sebagai salah satu destinasi utama bagi wisatawan domestik maupun mancanegara.

Ibu kota Bali adalah Denpasar, sementara tempat-tempat lain yang terus berkembang sebagai daerah pariwisata adalah Kuta, Sanur, Seminyak, Jimbaran dan Nusa Dua. Wilayah Ubud, kabupaten Gianyar dikenal sebagai pusat seni dan peristirahatan. Keindahan alam pulau Bali, didukung oleh kekayaan peninggalan budaya yang berupa candi-candi, istana kerajaan, museum serta berbagai peninggalan tradisional yang memiliki nilai sejarah.

Kebudayaan Bali mendapat pengaruh yang kuat dari kebudayaan India. Kerajaan Majapahit (1293-1500) yang beragama Hindu berpusat di pulau Jawa, saat itu hampir seluruh nusantara beragama Hindu, namun seiring datangnya Islam, berdirilah kerajaan-kerajaan Islam di Nusantara yang akhirnya menyebabkan keruntuhan kerajaan Majapahit. Pada masa itu, banyak bangsawan, pendeta dan masyarakat Hindu lainnya yang menyingkir dari pulau Jawa ke pulau Bali. Oleh karena itu orang Bali memandang dirinya sebagai pewaris kebudayaan Hindu yang telah ditinggalkan oleh tetangga-tetangganya di pulau Jawa. Di masa penjajahan Belanda, hanya sedikit gubernur Belanda yang memerintah memberikan pengaruhnya di pulau ini, sehingga pengendalian lokal terhadap agama dan budaya umumnya tidak berubah.Kebudayaan Bali pada hakikatnya berasal dari konsep keagamaan yang mengatur tingkah laku manusia yang dilandasi oleh agama Hindu (Laksemi, 2006). Bagi masyarakat Bali karya seni apapun wujudnya adalah refleksi kehidupan masyarakat dalam upaya mengungkapkan nilai yang mengandung keindahan, kemanusiaan, rasa bakti serta keselarasan antara lahir dan batin.

\section{Bangunan Tradisional Bali}

Bangunan tempat tinggal bagi masyarakat Bali dibangun sesuai dengan aturan Asta Kosala Kosali (bagian Weda yang mengatur tata letak ruangan dan bangunan layaknya fengshui dalam budaya Cina). Dalam filosofi masyarakat Bali, harmonisasi hidup akan tercapai apabila terwujud hubungan yang baik antara aspek pawongan (penghuni rumah), palemahan (hubungan baik antara penghuni rumah dengan lingkungannya) dan parahyangan. Oleh karena itu pembangunan sebuah rumah perlu memperhatikan aspek yang disebut dengan Tri Hita Karana. 


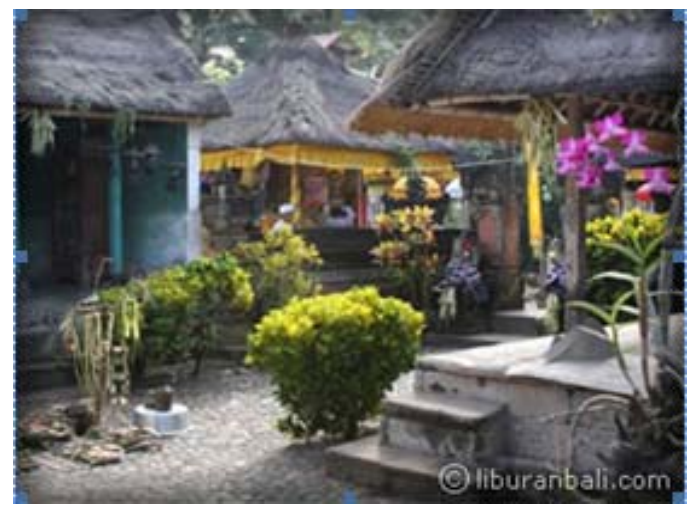

Gambar 1 Rumah penduduk Bali

(Sumber: http://www.liburanbali.com/image/paket/paket-rumah-bali.jpg)

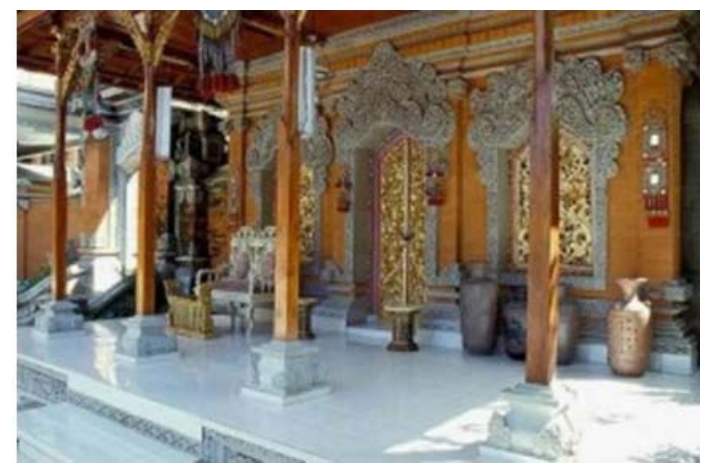

Gambar 2 Bangunan tradisional Bali

(Sumber: http://www.baliarchitectures.com/2009/06/arsitektur-rumah-bali/)

\section{Motif Ragam Hias Budaya Bali}

Pada umumnya bangunan atau arsitektur tradisional daerah Bali selalu dipenuhi hiasan, berupa ukiran, peralatan serta pemberian warna. Ragam hias tersebut mengandung arti tertentu sebagai ungkapan keindahan, simbol-simbol dan penyampaian komunikasi (Davison, Enu, Granquist, 2003). Namun saat ini ragam hias Bali sudah mulai beradaptasi dengan perkembangan zaman yang pengaruh modernisasi serta pabrikasi telah mengutamakan kepraktisan dan fungsi. Motif ragam hias Bali pada dasarnya hampir sama dengan ragam hias Padjajaran, ragam hias ini dinamakan Patre Punggel yang umumnya terlihat di Pura sebagai hiasan di pintu masuk.

Ragam hias Patre Punggel terdiri atas: (1) Bagian Pokok; merupakan perpaduan bentuk cekung dan cembung serta campuran daun ukuran besar atau tanggung, sehingga dari bentuk daun dapat diketahui jika daun ini adalah motif ukiran Bali. (2) Pokok Daun; merupakan sehelai daun yang tumbuh di tengah daun lainnya dan tertutup oleh angkup. Batas dan garis pokok berhimpitan dengan ulir muka dan masuk pada angkupnya. (3) Angkup; merupakan sehelai daun yang menutup daun pokok dari pangkal hingga ujung, dan pada ujung daunnya berulir. (4) Sunggar; sehelai daun yang tumbuh membalik di muka berbentuk krawingan yang pokoknya tumbuh dari ulir bagian benang. (5) Endong; sehelai daun yang selalu tumbuh di belakang daun pokok yang berbentuk cempalukan berulir atau daun punggel. (6) Trubusan; sehelai daun tambahan yang tumbuh di bagian ujung atas daun pokok sehingga menambah keindahan dari daun tersebut. (7) Simbar; sehelai daun tambahan yang tumbuh pada daun besar atau daun pokok di bagian bawah berdampingan dengan tangkai angkup. (8) Pecahan; suatu cawenan yang memisahkan daun pokok, terletak di tengah-tengah daun dan menambah baiknya dari suatu motif Bali. 


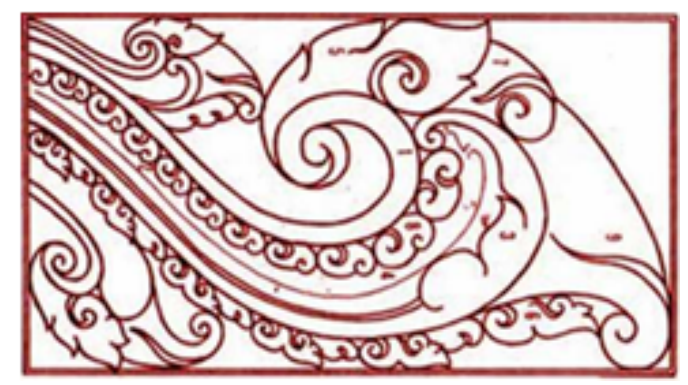

Gambar 3 Sketsa ragam hias Patre Punggel

(Sumber: http://blog-senirupa.blogspot.com/2013/09/ragam-motif-hias-klasik-tradisional.html)

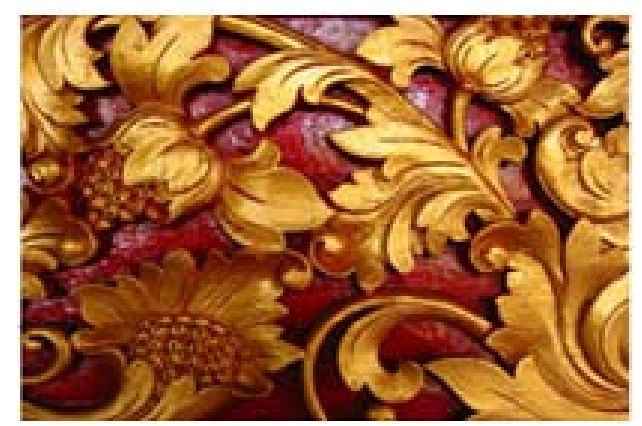

Gambar 4 Contoh ukiran Bali pada pintu masuk

(Sumber: http://gajahpare.blogspot.com/2012/03/motif-bali.html)

Keaslian ragam hias Bali sudah mulai jarang digunakan terutama pada bangunan publik, namun prinsip dari ragam hias ini masih perlu dilestarikan, agar para desainer interior ataupun arsitek Indonesia tetap memiliki pengetahuan dasar akan ragam hias Bali sebelum dapat mengaplikasikannya pada desain sebuah ruangan bernuansa Bali.

Pada dasarnya motif ragam hias Bali terdiri atas ornamen konstruktif dan ornament estetis. Masing-masing ornamen tersebut memiliki karakter yang sama, namun pembahasan pada penelitian ini akan dibatasi pada ornamen estetis saja. Menurut Drs. I Ketut Murdana, MSn, (Bali Post: 2007), ornamen estetis Bali ini terbagi atas empat karakter yaitu: (1) Geometris. (2) Floralistik. (3) Antrophomorfis / submorphosis (pola manusia atau hewan). (4) Perimbuhan (mengkombinasikan semua unsur alam benda)

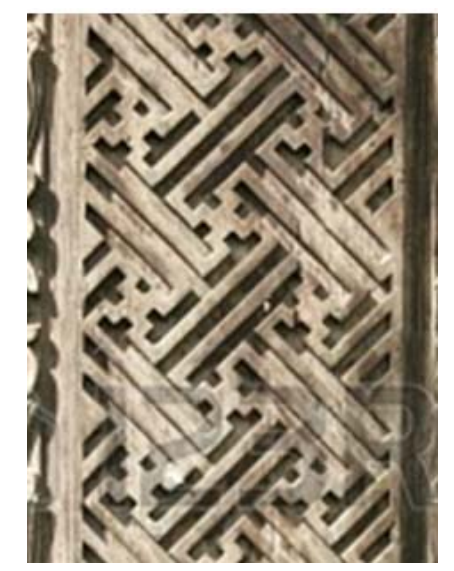

Gambar 5 Ornamen Geometris

(Sumber: http://www.123rf.com/photo_6558393_detail-of-old-decorative-wooden-panel-in-bali-indonesia.html) 


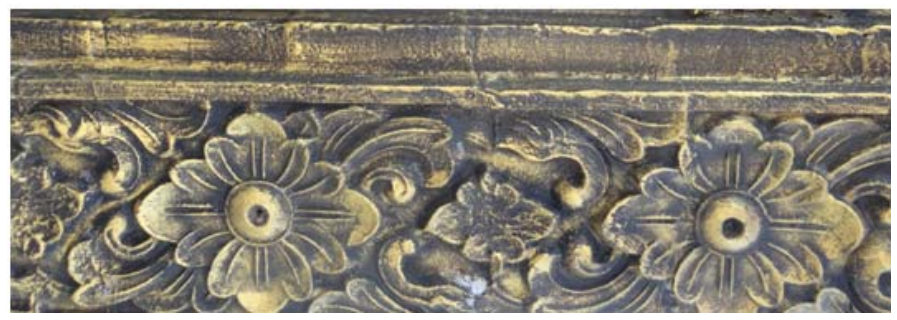

Gambar 6 Ornamen Floralistik

(Sumber: Polni, 2013)

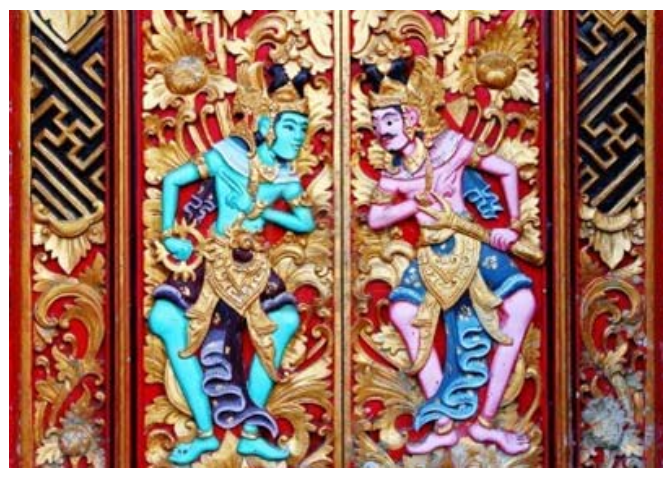

Gambar 7 Ornamen Antrophormosis: unsur bentuk manusia yang menampilkan kisah budaya ataupun religius

(Sumber: http://www.imagebali.net/images/artikel/564.jpg)

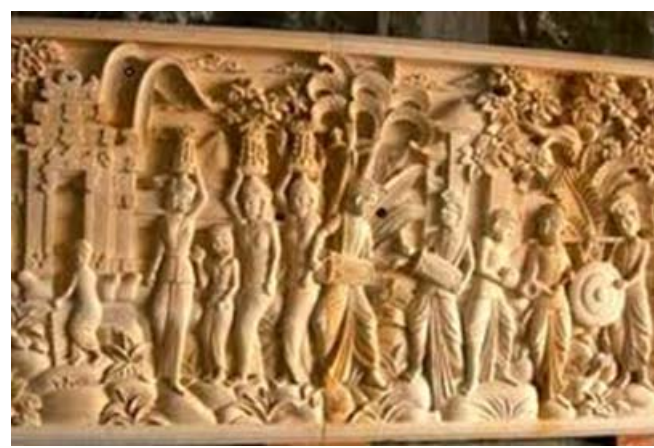

Gambar 8 Ornamen perimbuhan, yang mengkombinasikan semua unsur benda di alam (Sumber: Polni, 2013)

Dalam penerjemahannya, terlihat ragam hias dengan pola alam, Dewa dan Dewi yang menceritakan kisah pewayangan, ragam hias manusia yang disederhanakan, juga dijumpai ragam hias yang mendapatkan pengaruh dari budaya luar, seperti Cina, Islam, dan lain-lain. Kemudian perkembangan yang terjadi pada ornamen hias ini salah satunya adalah ragam hias berupa ekspresi dan kreasi imajinasi yang melahirkan bentuk-bentuk baru melalui pendekatan budaya, seni dan religius.

Selain pengelompokan dari jenis karakter, ragam hias Bali juga memiliki beberapa fungsi yang berbeda yaitu (Balika Ika: 2007): (1) Ragam hias untuk keindahan: ragam hias yang dimaksudkan untuk memperindah penampilan suatu bangunan yang dihias. Ketepatan dan keindahan hiasan dapat mempertinggi nilai suatu bangunan. Dengan mengaplikasikan hiasan penampilan suatu bangunan akan lebih indah dan menyegarkan pandangan. (2) Ragam hias untuk ungkapan simbolis: selain dari berbagai macam, bentuk dan penempatan, ragam hias juga dapat mengungkapkan simbol 
yang terkandung di dalamnya, pemilihan warna juga dapat mengungkapkan simbol arah orientasi yaitu merah untuk warna kelod (utara), kuning untuk warna kauh (barat), putih untuk warna kangin (timur) dan hitam untuk warna kaja (selatan), serta penyatuan dua warna bersisian untuk arah sudut. (3) Ragam hias sebagai alat komunikasi: dilihat dari bentuk hiasan yang digunakan pada upacara atau bangunan-bangunan tertentu.

\section{Pintu Bali}

Kori Kuwadi adalah pintu tradisional Bali dan merupakan bagian dari arsitektur Bali tradisional. Dahulu, kori kuwadi hanya dimiliki oleh keluarga kerajaan dan Brahmana (para pemuka agama Hindu) dan umumnya berada pada bangunan saka roras (yaitu bangunan dengan 12 tiang). Namun saat ini kori kuwadi sudah menjadi produksi masal dan dapat diaplikasikan pada tempat umum (Balika Ika: 2007).

Pintu Bali terdiri dari empat batang kayu yang menyusun sebuah bingkai, dimana masingmasing batang kayu telah memiliki bentuk, fungsi dan makna yang berbeda. Pintu ini memiliki dua daun pintu dengan kayu melintang di bagian bawah yang disebut dengan dedanga. Ukuran standar dari pintu adalah 60 × $200 \mathrm{~cm}$ dan memiliki dua buah daun pintu. Sementara ukuran maksimal dari pintu ukir Bali adalah 110 × $200 \mathrm{~cm}$. Material dari pintu ukir bali umumnya dalah kayu jati (teak wood) dan kayu nangka (jackfruit wood). Pemilihan jenis kayu ini tergantung dari penempatan dari pintu, khususnya pintu untuk bangunan tempat ibadah seperti pura, tentu berbeda dengan kayu untuk pintu pada bangunan umum dan perumahan.

Saat ini kori kuwadi menjadi ciri khas dalam bangunan berarsitektur Bali, hal ini menandakan adanya pergeseran nilai filosofi yang awalnya melambangkan kemewahan menjadi sebuah sebuah elemen yang hanya berfungsi dekoratif.



Gambar 9 Kori kuwadi, pintu bali yang pada awalnya hanya dimiliki oleh keluarga kerajaan (Sumber: http://galihukir.files.wordpress.com/2011/03/dscn2048.jpg)

Pintu Bali yang memiliki dua daun pintu menyerupai desain pintu di wilayah India Selatan, baik dari segi warna, pegangan pintu serta sistem penguncinya. Ragam hias dari pintu telah melalui beberapa era, yaitu mulai dari tiga warna sederhana yang umum dijumpai pada rumah-rumah desa di pengunungan, sampai dengan pahatan berupa ukiran dengan nuansa warna chinoiserie pada pintupintu istana di wilayah Gianyar, Klungkung dan Karangasem yang popular pada abad 20an (Wijaya, 2002). 


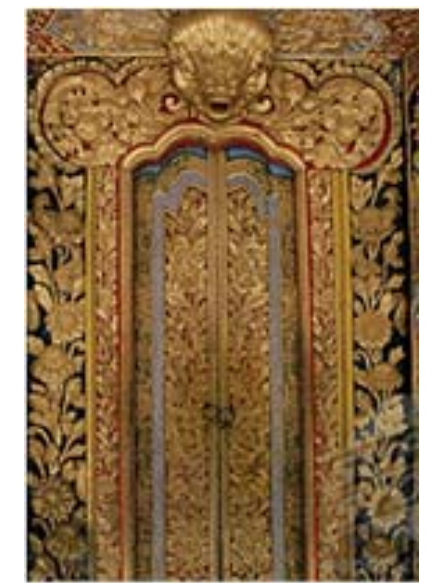

Gambar 10a Pintu istana Gianyar kedua pintu ini memiliki ragam hias yang dipengaruhi gaya chinoserie (Sumber: Polni, 2013)



Gambar 10b Pintu istana Karangasem

\section{Ragam Hias Pada Bangunan dan Pintu Bali}

Ragam ukiran yang tampak pada pintu Bali umumnya menampillkan ragam flora dan fauna yang memiliki beberapa istilah dan pengertian khusus (Wijaya, 2002).

\section{Flora}

Bentuknya yang mendekati keadaan sebenarnya ditampilkan sebagai latar belakang hiasanhiasan bidang dalam bentuk hiasan atau pahatan relief. Cerita-cerita pewayangan, legenda, dan kepercayaan yang dituangkan ke dalam lukisan atau pahatan relief umumnya dilengkapi dengan latar belakang berbagai macam tumbuh-tumbuhan yang menunjang penampilannya.

Berbagai macam flora ditampilkan sebagai hiasan dalam bentuk simbolis atau pendekatan bentuk-bentuk tumbuh-tumbuhan yang dipolakan dalam bentuk pepatraan dengan berbagai macam ungkapan atau peralatan dan perlengkapan bangunan dari jenis-jenis flora yang dinamai sesuai jenis dan keadaanya.

\section{Keketusan}

Mengambil sebagian terpenting dari suatu tumbuhan yang dipolakan berulang dengan pengolahan untuk memperindah penonjolannya. (a) Keketusan wangga umumnya ditatahkan pada bidang-bidang luas atau peperadaan lukisan cat prada warna emas pada lembar-lembar kain hiasan. (b) Keketusan tuwung / bungan, hiasan berpola bunga terung dipolakan dalam bentuk liku-liku segi banyak, berulang atau bertumpuk menyerupai bentuk bunga terung. (c) Keketusan bun-bunan, hiasan berpola tumbuh-tumbuhan jalar bersulur memperlihatkan jajar-jajar jalaran dan sulur-sulur di sela-sela bunga dan dedaunan.

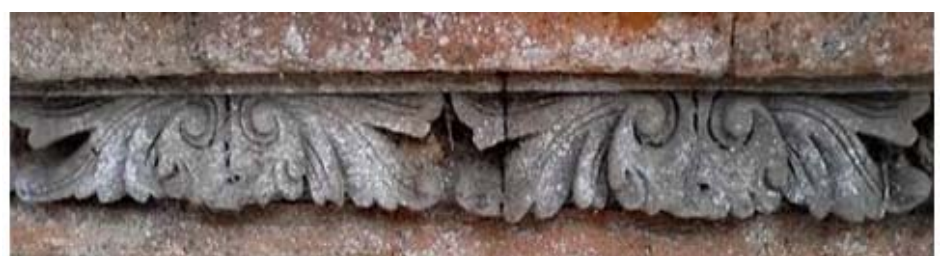

Gambar 11 Ragam hias keketusan

(Sumber: Polni, 2013) 
Ornamen keketusan memiliki makna yang mengikat sifat positif yaitu terpenuhinya kebutuhan akan sandang, pangan serta papan dan tercapainya hidup rukun, damai sejahtera di dunia maupun di akhirat.

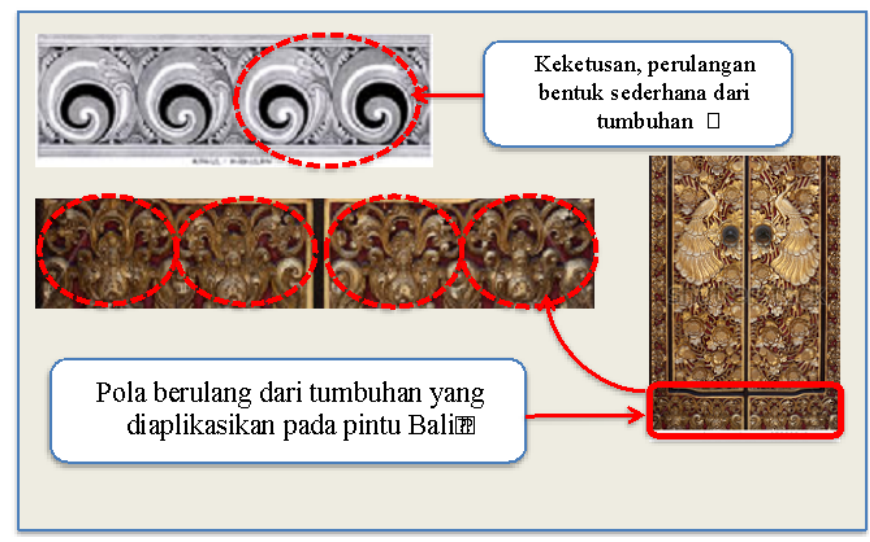

Gambar 12 Penerapan ragam hias keketusan pada pintu

\section{Kekarangan}

Kekarangan menampilkan suatu bentuk hiasan dengan suatu karangan yang berusaha mendekati bentuk-bentuk flora yang ada dengan penekanan bagian-bagian keindahan. Seperti jenis keketusan ataupun pepatran, jeniskekarangan sangat banyak ditemukan dalam ragam hias tradisional Bali. Kakarangan yang umum dijumpai adalah: (a) Karang simbar suatu hiasan rancangan yang mendekati atau serupa dengan tumbuh-tumbuhan lekar dengan daun terurai ke bawah yang namanya simbar menjangan. Karang simbar dipakai untuk hiasan-hiasan sudut bebaturan di bagian atas pada pasangan batu atau tatahan kertas pada bangunan, badewadah, bukur atau hiasan-hiasan sementara lainnya. (b) Karang bunga, suatu hiasan rancangan yang berbentuk bundar dengan kelopak dan seberkas daun yang juga digunakan untuk hiasan sudut-sudut bebaturan atau hiasan penjolan bidang-bidang. (c) Karang suring, suatu hiasan yang menyerupai serumpun perdu dalam bentuk kubus yang difungsikan untuk sendi alas tiang tugeh yang dalam bentuk lain dipakai bersayap garuda. Karangan suring yang diukir dalam-dalam, memungkinkankan karena tiang tugeh bebas beban.

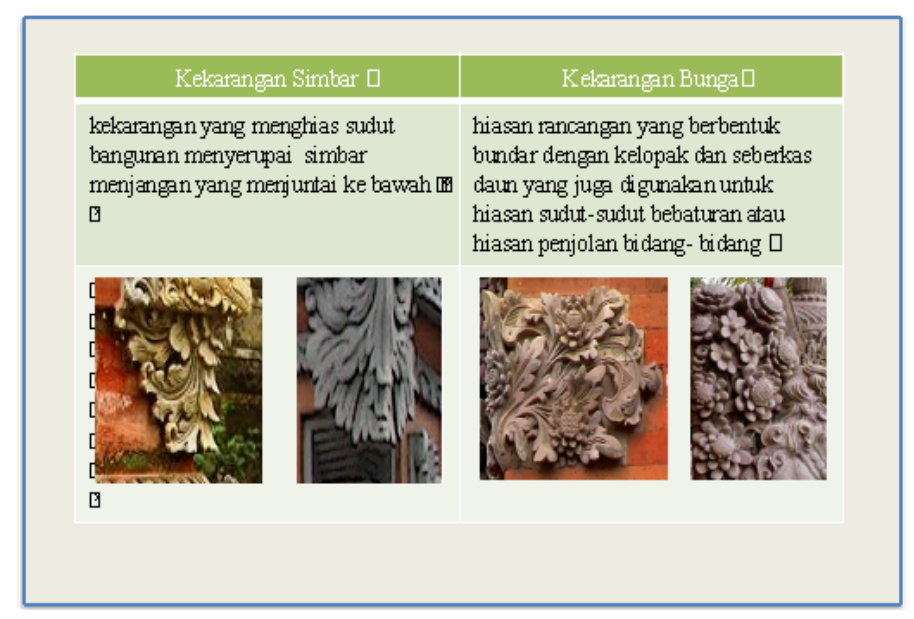

Gambar 13 Kakarangan Simbar dan kekarangan Bunga 


\section{Pepatraan}

Jenis ragam hias ini berwujud gubahan-gubahan keindahan hiasan dalam patern-patern yang juga disebut patra. Ide dasar pepatraan banyak diambil dari bentuk-bentuk keindahan flora. Keindahan flora diambil sedemikian rupa sehingga jalur daun, bunga, putik dan ranting dibuat berulang-ulang. Masing-masing patra memiliki identitas yang kuat, sehingga mudah diketahui namun dapat bervariasi dalam penerapannya.

Makna dari pepatraan adalah memberikan perlindungan kepada kehidupan manusia dari rasa takut, panas dan haus, sehingga memberikan kenyamanan bagi manusia yang tiggal di lingkungan bangungan yang dihiasi pepatraan. Pepatraan ini terbagi atas: (a) Patra Wangga, tergolong kekerasan yang merupakan sebagian dari suatu flora dengan penampilan bagian-bagian keindahannya. (b) Patra Sari, bentuknya menyerupai flora dari jenis berbatang jalar melingkar, linggar balik berulang. Penonjolan sari bunga merupakan identitas pengenal sesuai namanya patra sari. Daundaun dan bunga dilukiskan dalam pola yang diperindah. Patra sari dapat digunakan pada bidangbidang lebar atas, daun umumnya untuk bidang-bidang sempit, tidak bisa dibuat dalam banyak variasi karena lingkar-lingkar batang jalar, daun-daun sari, kelopak dan daun bunga merupakan pola-pola tetap sebagai identitas. (c) Patra bun-bunan, dapat bervariasi dalam berbagai jenis flora yang tergolong bun-bunan (tumbuh-tumbuhan berbatang jalar). Dibuat dengan pola berulang antara daun dan bunga di rangkai batang jalar. Dapat pula dibuat variasi dengan julur-julur dari batang jalar. (d) Patra Pidpid, juga melukiskan flora dari jenis daun bertulang tengah dengan daun-daun simetris yang dapat bervariasi. Jenis daun yang dilukiskan ditempatkan pada bidang sempit. (e) Patra Punggel, mengambil bentuk dasar liking paku, sejenis flora dengan lengkung-lengkung daun muda pohon paku. Bagianbagiannya ada yang disebut batu pohon kupil guling dan util sebagai identitas. Patra punggel merupakan patra yang paling banyak digunakan. Selain bentuk yang murni sebagai Patra Punggehutuh. Patra punggel umumnya melengkapi segala bentuk kekarangan (patra-patra jenis fauna) sebagai hiasan bagian (lidah naga patra punggel api-apian), ekor singa dan hiasan-hiasan untuk patra tunggal puncak atap yang disebut bantala pada atap yang bukan berpuncak satu. Untuk hiasan atas berpuncak satu dipakai bentuk Murdha dengan motif-motif KusumaTirta Amertha Murdha Bajra yang masing-masing juga dilengkapi dengan patra punggel sebagai hiasan bagian dari Karang Goak pada sudut alas Murdha. (f) Patra Samblung, pohon jalar dengan daun-daun lebar dibuat dalam bentuk pola yang disebut dengan Patra Samblung. Ujung-ujung pohon jalar melengkung dengan kelopak daun dan daun-daun dihias denga lengkung-lengkung harmonis. Serupa dengan Patra Samblung, Patra Olanda, Patra Cina dan Patra Bali, masing-masing patra tersebut dengan kemungkinan diberi nama berdasarkan negara asalnya. Ada pula Patra Banci yang bervariasi dari gabungan patra yang dirangkai dalam satu kesatuan serasi dengan mewujudkan identitas baru. (g) Patra Pae, mengambil bentuk tumbuh-tumbuhan sejenis kapu-kapu yang dibuat dalam bentuk pola berulang berjajar memanjang. (h) Patra Ganggong, menyerupai bentuk tumbuh-tumbuhan ganggang air yang dibuat dalam bentuk pola berulang berjajar memanjang. (i) Patra Batun Timun, bentuk dasar serupa biji mentimun yang dibuat dalam susunan pola diagonal berulang.Sela-sela susunan dihias dengan bentuk-bentuk para mas-masan setengah bidang. (j) Patra Sulur, melukiskan pohon jalar jenis beruas-ruas dengan daun-daun sulur bercabang-cabang tersusun, berulang. Patra Sulur dipolakan pula dalam bentuk tiga jalur batang jalar teranyam berulang. 




Gambar 14 Ragam jenis pepatraan dan rangkaian patra punggel (Sumber: http://blog.isi-dps.ac.id/agungjayack/ornamen-pepatran )

\section{Fauna}

Dijadikan materi hiasan dalam bentuk ukiran, tatahan atau pepulasan. Penerapannya merupakan pendekatan dari keadaan sebenarnya.Pada beberapa bagian keadaan sebenarnya dikombinasikan dengan bentuk-bentuk penyesuaian untuk menampilkan keindahan yang harmonis dengan pola hias keseluruhan.

Sebagai materi hiasan, fauna dipahatkan dalam bentuk kekarangan yang merupakan pola tetap, relief yang berkombinasi dengan berbagai macam bentuk binatang. Penempatan hiasan fauna pada umumnya disertai atau dilengkapi dengan jenis-jenis flora yang disesuaikan. Fauna sebagai patung hiasan pada bangunan umumnya mengambil jenis kera dan cerita Ramayana. Patung-patung sebagai suvenir umumnya mengambil bentuk-bentuk garuda, naga, singa, kuda, kera, sapi dan binatang ternak lainnya.

Ukiran fauna pada bidang-bidang relief di dinding, panel atau bidang-bidang ukiran lainnya biasanya menerapkan kisah rakyat atau legenda dari dunia binatang. Penampilan fauna dalam bentuk patung-patung bercorak ekspresionis tampak pada kekarangan bercorak abstrak dan realis pada relief. Fauna sebagai hiasan juga berfungsi sebagai simbol-simbol ritual yang ditampilkan dalam bentuk patung yang disebut Pratima, patung sebagai bagian dari bangunan berbentuk Bedawang Nala. Fauna sebagai corak magis, lengkap dengan huruf-huruf berupa simbol mantra-mantra. Fauna sebagai elemen bangunan juga berfungsi sebagai ragam hiasan yang dikenakan sebagai sendi alas tiang dengan bentuk-bentuk garuda, singa bersayap atau bentuk-bentuk lainnya.

Ragam hias dari jenis-jenis fauna ditampilkan sebagai materi hiasan dengan nama masingmasing. Bentuk-bentuk penampilannya berupa patung.

\section{Kekarangan}

Kekarangan memiliki gaya ekspresionis, yaitu meninggalkan bentuk sebenarnya sehingga fauna ditampilkan secara abstrak. Berikut adalah kekarangan yang mengambil bentuk-bentuk binatang khayal primitif yang dinamai sesuai dengan bentukannya. (a) Karang Boma. Berbentuk kepala raksasa yang dilukiskan dari leher ke atas lengkap dengan hiasan dan mahkota, diturunkan dari cerita Baomantaka. Karang Boma ada yang tanpa tangan ada pula yang lengkap dengan tangan dari pergelangan ke arah jari dengan jari-jari mekar.Karang Boma umumnya dilengkapi dengan Patra Bunbunan atau Patra Punggel. Ditempatkan sebagai hiasan di atas lubang pintu dari Kori Agung. 




Gambar 15 Karang Boma, yang dilengkapi dengan Patra Bun-bunan atau Patra Punggel

(Sumber: Polni, 2013)

(b) Karang Sae. Berbentuk kepala kelelawar raksasa seakan bertanduk dengan gigi runcing. Umumnya dilengkapi dengan tangan seperti Karang Boma. Penampilannya dilengkapi dengan flora Patra Punggel dan Patra Bun-bunan. Hiasan ini berada di Pinti Kori atau pintu rumah tinggal dan beberapa tempat lainnya. (c) Karang Hasti (Asti). Disebut pula Karang Gajah karena Asti adalah Gajah. Bentuknya mengambil inspirasi dari bentuk gajah yang digambar abstrak sesuai dengan bentuk kekarangan. Karang Asti yang melukiskan kepala gajah dengan belalai dan taring gadingnya bermata bulat. Hiasan Patra Punggel melengkapi ke arah sisi pipi gajah. Sesuai kehidupannya gajah di tanah Karang Asti ditempatkan sebagai hiasan pada sudut-sudut bebatuan di bagian bawah.

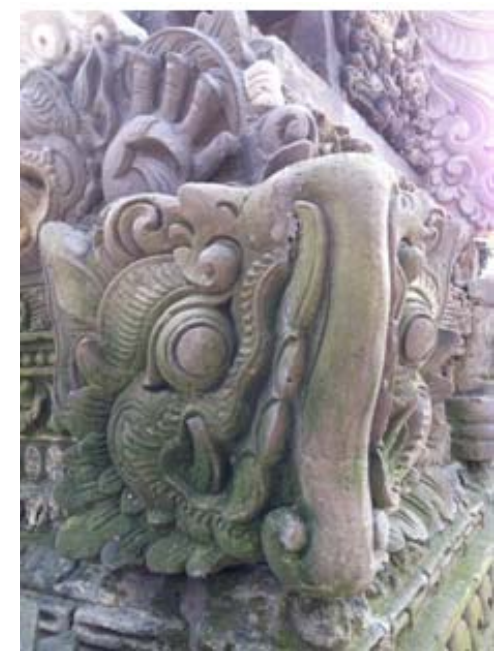

Gambar 16 Karang Asti, berupa gajah dengan belalai dan mata bulat, sebagai hiasan pada sudut batuan pada bagian bawah bangunan

(Sumber: Polni, 2013)

(d) Karang Goak. Bentuknya menyerupai kepala burung gagak atau goak.Disebut pula karang manuk karena serupa pula dengan kepala ayam dengan penekanan pada paruhnya. Karang Goak dengan paruh atas bertaring dan gigi-gigi runcing mata bulat. Sesuai dengan kehidupan manuk atau gagak sebagai binatang bersayap, hiasan karang manuk yang juga disebut Karang Goak ditempatkan pada sudutsudut bebaturan di bagian atas. Karang Goak sebagai hiasan bagian pipi dan kepalanya dilengkapi dengan hiasan Patra Punggel. Karang Goak umumnya disatukan dengan karang simbar dari jenis flora yang ditempatkan di bagian bawah Karang Goak. 


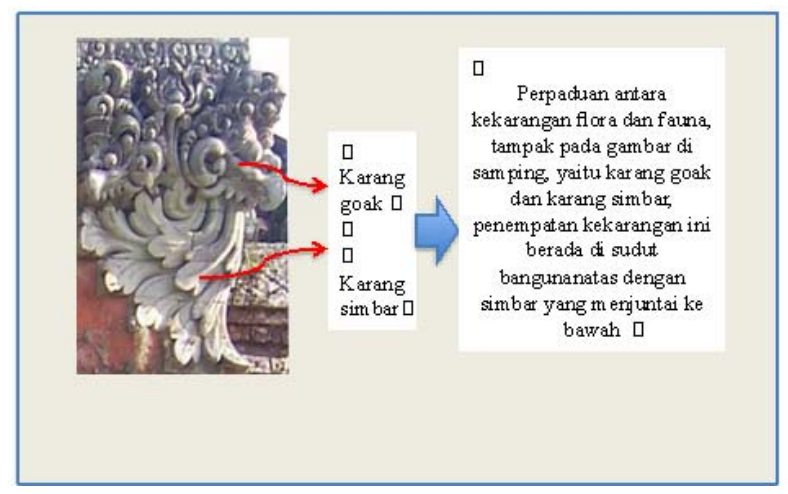

Gambar 17 Perpaduan karang goak dan karang simbar (Sumber: Polni, 2013)

\section{Penerapan Ragam Hias Bali pada Interior Public Space}

Sesuai dengan fungsi utama ragam hias yaitu sebagai elemen dekoratif yang menambah nilai estetika bangunan. Fungsi ragam hias sebagai unsur estetika bangunan dapat ditunjukkan melalui bentuk, warna, tekstur, bahan, material, penyusunannya serta unsur seni yang terpadu dengan harmonis. Ragam hias sebagai ornamen eksterior bangunan menyatu dengan lingkungan sekitarnya. Pada umumnya bangunan Bali lebih menonjolkan pengolahan eksterior bangunan daripada interiornya untuk menunjukkan kesan keterbukaan dan status sosial penghuninya.Sedangkan ragam hias pada interior bangunan lebih dimaksudkan untuk menimbulkan suasana alam Bali yang indah, tenang, damai dan sejuk.

Ornamen merupakan seni terapan yang memiliki nilai estetika sendiri walaupun hanya sebatas sebagai hiasan. Dalam pembuatannya ornamen tidak akan terlepas dalam maksud dan tujuannya. Walaupun sebenarnya fungsi murni estetis merupakan fungsi ornamen untuk memperindah penampilan bentuk produk maupun obyek yang dihiasi sehingga menjadi sebuah karya seni.

Fungsi simbolis ornamen pada umumnya dijumpai pada produk atau benda upacara atau benda pusaka yang bersifat keagamaan atau kepercayaan yang menyertai nilai estetiknya. Hal ini membuktikan bahwa motif yang terdapat dalam arsitektur tradisional Bali memiliki maksud dan arti yang baik secara estetis maupun keindahan. Hal ini terlihat dalam sifat masyarakat Bali yang masih sangat melekat dengan tradisi dan kepercayaan Hindunya sehingga pada bangunan tradisionalnya pun mengandung banyak makna.

Pengaplikasian ragam hias Bali dapat ditemukan pada interior maupun eksterior. Dalam ruang dalam, bisa diterapkan pada elemen-elemen interior, misalkan dinding, lantai, maupun ornamenornamen.Yang tidak boleh dilupakan juga adalah furnitur pendukung interior, misalkan meja dan kursi. Namun ragam hias Bali biasa tidak ditemukan pada furnitur, karena makna dan simbol religi Bali lebih banyak digunakan pada bangunan. Dari sekian banyak ragam hias yang ada, dimana masing-masing memiliki makna tersendiri, ditemukan kesamaan motif dan makna. Public space yang lebih mudah untuk dieksplor dan dapat terlihat jelas pengaplikasian ragam hias Bali antara lain adalah restoran.

Berikut beberapa analisa dari ragam hias Bali yang diaplikasikan di Restoran Jimbaran, Ancol. Dengan pembanding, restoran The Ubud, Bebek Bengil di kawasan Menteng. Dari dua restoran ini, dapat kita lihat bagaimana pengaplikasian motif ragam hias Bali dewasa ini pada public space. 


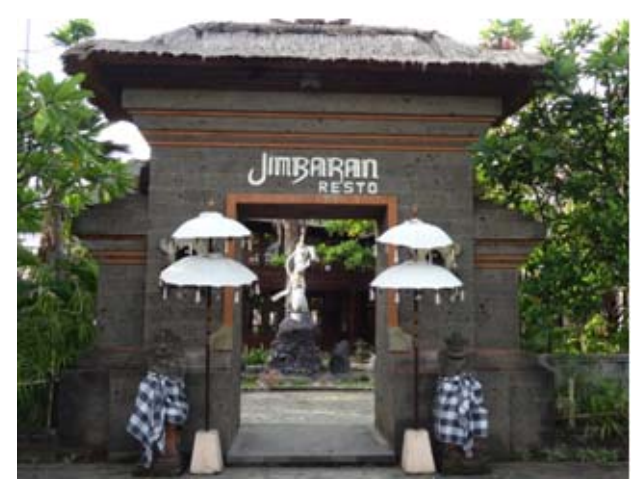

Gambar 18 Gerbang Masuk Jimbaran Resto

(Sumber: Polni, 2013)

Restoran Jimbaran adalah restoran yang bernuansakan Bali dalam arsitektur, suasana, pelayanan dan makanan khas Bali. Berlokasi di dalam Taman Impian Jaya Ancol, restoran ini memperlihatkan gaya Bali yang kental. Sebelum masuk ke dalam area restoran, terlihat gerbang pintu masuk bergaya Bali seperti yang tampak pada gambar di atas. Kiri kanan gerbang terdapat arca patung Bali berbalut kain kotak hitam putih khas Bali yang disebut saput poleng. Saput adalah bahasa Bali yang berarti selimut, sedangkan poleng bermakna belang.

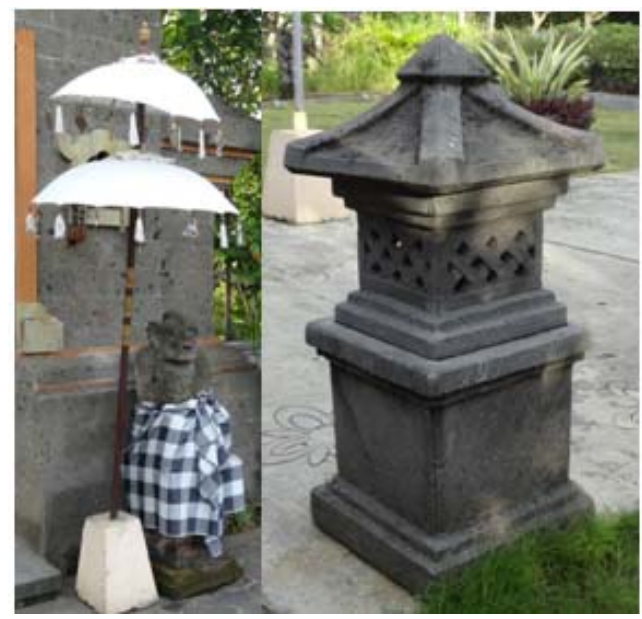

Gambar 19 Detil Ornamen Bali Pada Pintu Gerbang (Sumber: Polni, 2013)

Arca patung dan pahatan yang terlihat pada gambar di atas, fungsinya lebih banyak berkaitan dengan fungsi hias, meskipun ada juga arca patung dan pahatan yang berkaitan dengan seni pakai (aplied art) dan fungsi yang berkaitan dengan religi (keagamaan). Sebagai karya seni tiga dimensi, maka perwujudan patung didasarkan atas ukuran panjang, lebar dan tinggi.

Dalam fungsinya sebagai benda seni yang bernilai profan, maka patung Bali bisa dijadikan benda pajang di dalam ruangan (dekorasi interior) atau dipajang di luar ruangan (dekorasi taman). Dalam fungsinya sebagai benda seni untuk hiasan inilah, di masa kini patung Bali sangat bervariasi wujud dan kreasinya, terutama setelah bersentuhan dengan dunia pariwisata. Karena itulah di masa kini, patung Bali tidak lagi hanya berwujud patung-patung tradisional dari dunia pewayangan, tidak lagi hanya berwujud patung dewa-dewa dan patung-patung tokoh tradisional seperti raja atau orangorang suci, tetapi sudah dengan berbagai kreasi baru. 
Arca patung Bali selalu dipakai kain poleng dimana masyarakat mempercayai kain poleng memiliki makna filosofinya adalah dua sifat yang bertolak belakang, yakni hitam-putih, baik-buruk, panjang-pendek, tinggi-rendah, dan sebagainya.

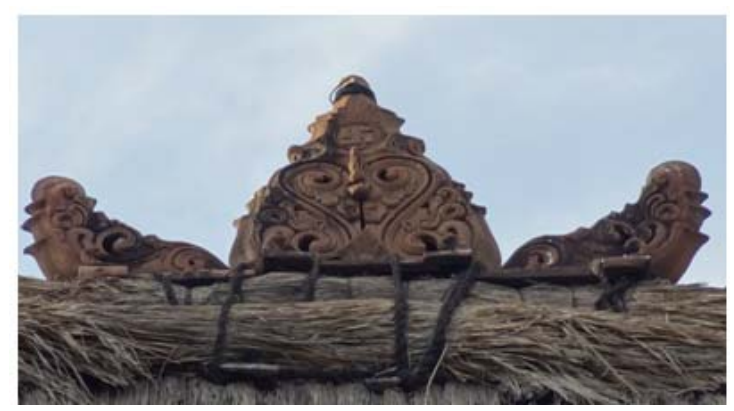

Gambar 20 Ornamen Ukiran Bagian Atas Gerbang (Sumber: Polni, 2013)

Pada bagian atas gerbang terdapat ukiran motif Bali dengan pola sulur tumbuhan. Dimana motif ini berupa suatu tumbuhan yang dibuat dengan pola berulang dengan pengolahan untuk memperindah penonjolannya. Dapat terlihat kesimetrisan pada pahatan ukiran melambangkan keselarasan dan keseimbangan dalam konsep Bali.

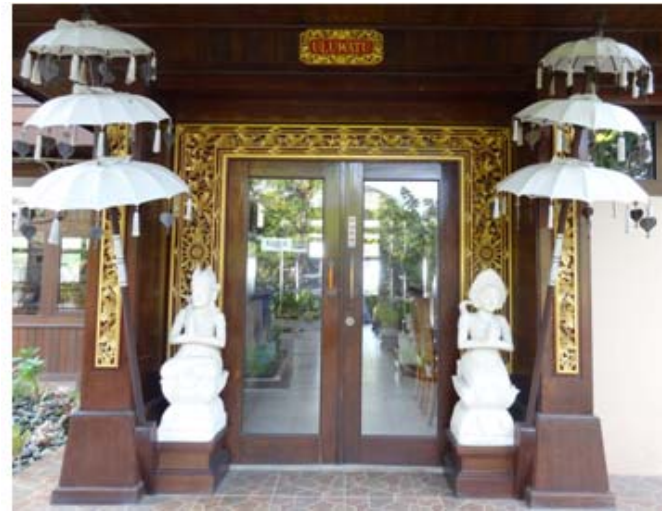

Gambar 21 Entrance Area Makan pada Restoran Jimbaran (Sumber: Polni, 2013)

Pada pintu masuk menuju ruang makan Restoran Jimbaran Ancol, terlihat dua arca patung bali tradisional tanpa balutan kain hitam putih yang dikenal dengan sebutan kain poleng, namun ornamen pada pintu masih kental dengan motif Bali. Warna prada tetap mengikuti ornamen pintu, dengan motif sulur tanaman sebagai simbol kepercayaan. Tidak ketinggalan sepasang payung yang menaungi arca patung sebagai simbol perlindungan dan peneduhan.



Gambar 22 Papan Nama Ruang Area Makan (Sumber: Polni, 2013) 
Pada bagian atas pintu masuk setiap ruang makan tampak nama ruang yang ditulis diatas papan kayu yang telah diberi ukiran motif Bali. Dengan tulisan berwarna keemasan dan latar belakang merah, mencerminkan warna Bali yang sarat dengan merah dan kuning. Terlihat masih dengan motif salur tumbuhan, terdapat helaian daun yang tumbuh di bagian ujung daun lainnya terus menerus hingga menyambung dan mengelilingi papan tulisan tersebut. Pengaplikasian motif Bali pada papan nama ruang makan cukup signifikan dalam membawa nuansa Bali pada restoran.

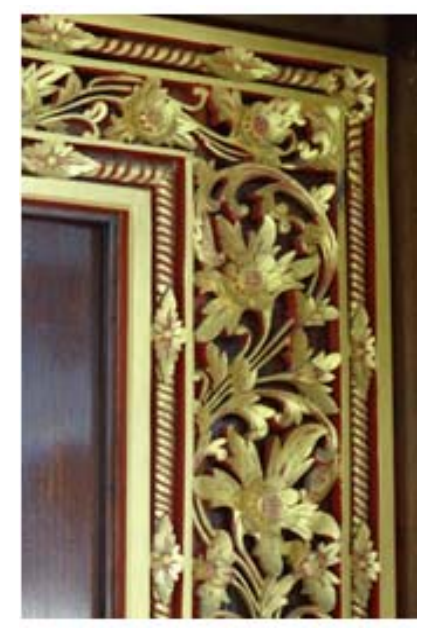

Gambar 23 Motif Ornamen Sekeliling Pintu (sumber : Polni, 2013)

Sekeliling pintu masuk restoran, diberi ornamen ragam hias keketusan. Gambar diatas merupakan contoh keketusan pada ragam hias Bali, dimana mengambil bagian terpenting dari suatu tumbuhan dan dibuat dengan pola berulang dengan pengolahan untuk memperindah penonjolannya. Tampak sulur dan bunga yang sambung menyambung terkesan seolah berulang dalam satu pola mengelilingi tiga sisi daun pintu masuk. Warna selalu dikaitkan dengan warna Bali yakni emas dan merah.

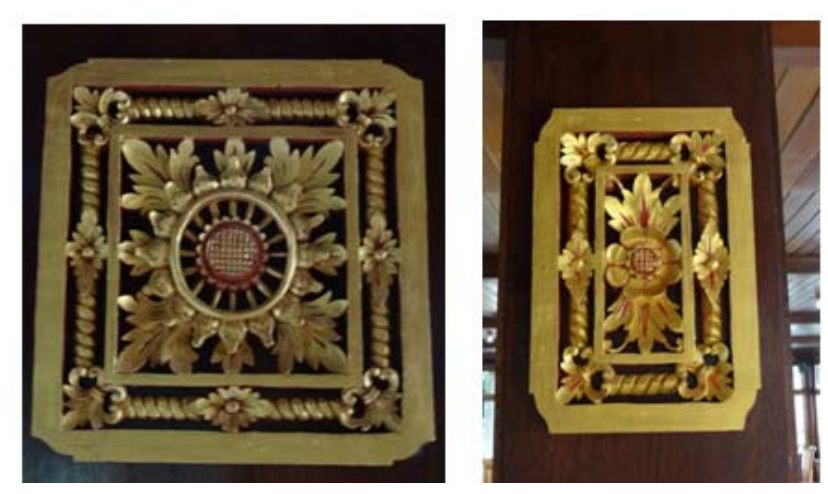

Gambar 24 Motif Ornamen Khas Bali Pada Pilar Dinding (Sumber: Polni, 2013)

Pada area ruang makan dalam, terdapat pilar-pilar dinding yang dihiasi dengan ornamen seperti tampak pada gambar di atas. Motif yang biasa mewakili motif tanaman adalah sulur-sulur dan bunga serta daun, dimana motif bunga teratai banyak ditemukan dan merupakan asimilasi dari motif Hindu, terbagi menjadi padma, uthpala dan kumada. 


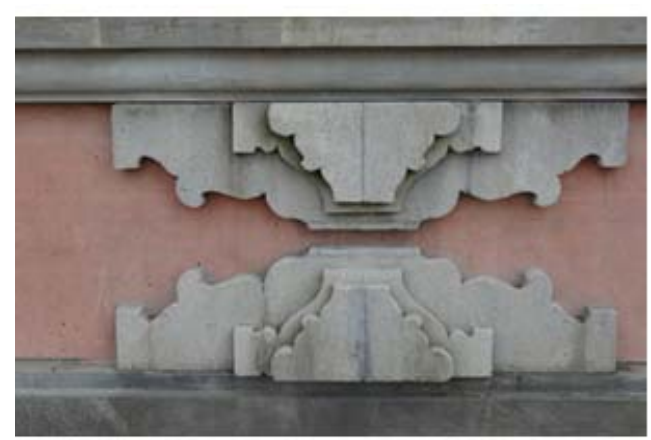

Gambar 25 Ornamen Ukiran Sisi Dinding Panggung (Sumber: Polni, 2013)

Pada panggung yang terdapat di restoran Jimbaran Ancol ini, ke dua sisi kiri dan kanan panggung terdapat ukiran ornamen seperti pada gambar di atas. Bentuk yang diambil menyerupai flora, bertumpuk dan simetris.Bentuk model diatas banyak dijumpai di adat Bali, mewakilkan keseimbangan dan keselarasan.

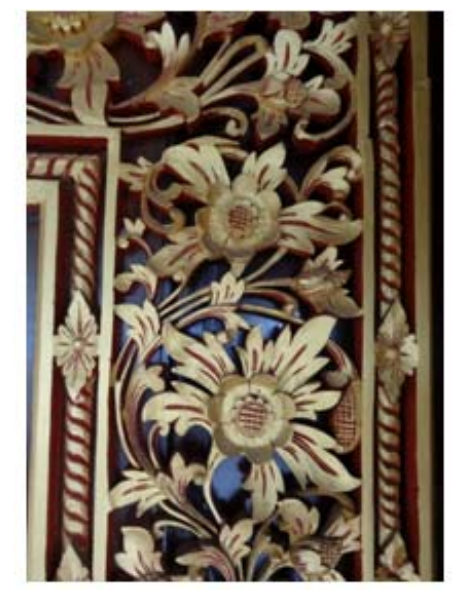

Gambar 26 Detil Ornamen Sekeliling Pintu Masuk (1) (Sumber: Polni, 2013)

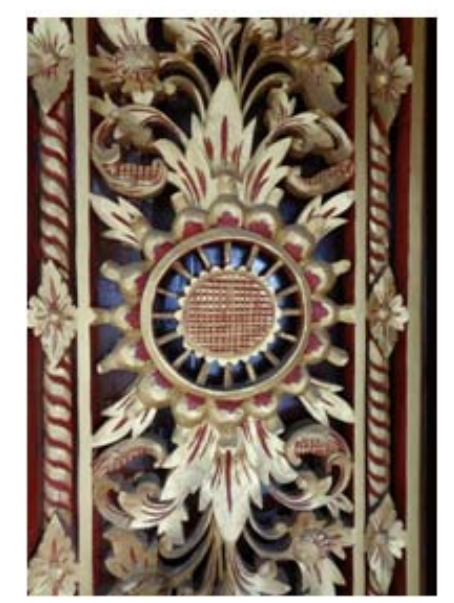

Gambar 27 Detil Ornamen Sekeliling Pintu Masuk (2) (Sumber: Polni, 2013) 
Motif ragam hias Bali hampir menyerupai ragam hias Padjajaran, dimana motif berbentuk ukel dari daun pakis dan bentuknya serba bulat. Bentuk ukel seperti tanda koma. Bedanya pada motif ragam hias Bali terletak pada ujung ukel yang dihiasi dengan sehelai patran. Jadi ukel besar kecil, bulet cekung, pecahan, ada pula daun yang runcing. Biasa dinamakan Patre Punggel. Ragam hias ini dapat dilihat sebagai hiasan pintu masuk, juga di kota-kota besar yang sudah banyak didapatkan patungpatung Bali klasik, seperti halnya pada restoran Jimbaran Ancol ini.

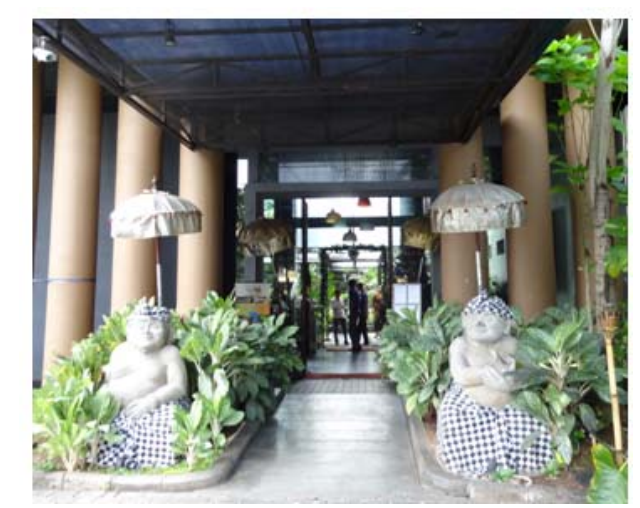

Gambar 28. Pintu Masuk Restoran The Ubud, Bebek Bengil (sumber : Polni, 2013)

Gambar diatas adalah tampak muka restoran The Ubud yang berlokasi di kawasan Menteng. Restoran yang menyajikan makanan khas Bali ini kurang menampilkan eksterior maupun interior bergaya Bali. Pada selasar menuju pintu masuk terdapat dua buah arca patung sebagai perlambang penjaga yang dililit dengan kain poleng, dan payung berteduh, sebagai makna perlindungan. Hanya ini yang terlihat mewakili nunasa Bali.Pintu masuk sudah sangat modern, dengan paduan kaca dan kayu. Tidak terdapat ornamen ukiran bali pada pintu.

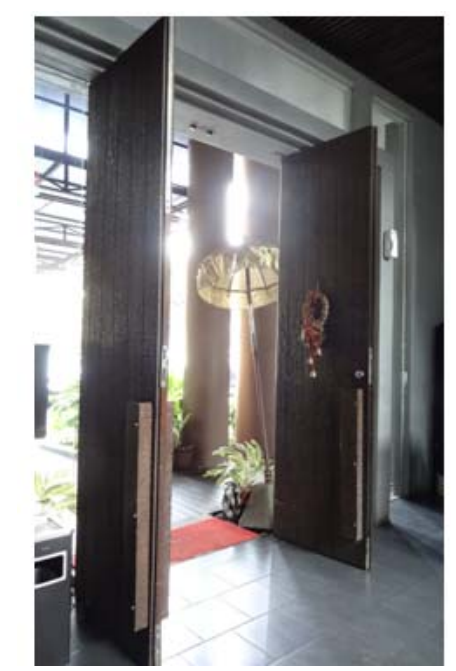

Gambar 29 Model Pintu Masuk Restoran The Ubud

(Sumber: Polni, 2013)

Restoran The Ubud lebih terkesan modern terlihat dari desain pintu, maupun furnitur di dalam area ruang makan. Tidak disisipkan motif ukiran Bali sama sekali pada pintu masuk. Sama seperti area selasar menuju pintu masuk, pada depan pintu ini terdapat dua payung khas Bali sebagai lambang 
perlindungan dan kesejukan, dan kain poleng tidak ketinggalan menghiasai pot tanaman di depannya. Dapat dikatakan bahwa restoran ini lebih bergaya modern, sehingga tidak diaplikasikan motif Bali yang signifikan.

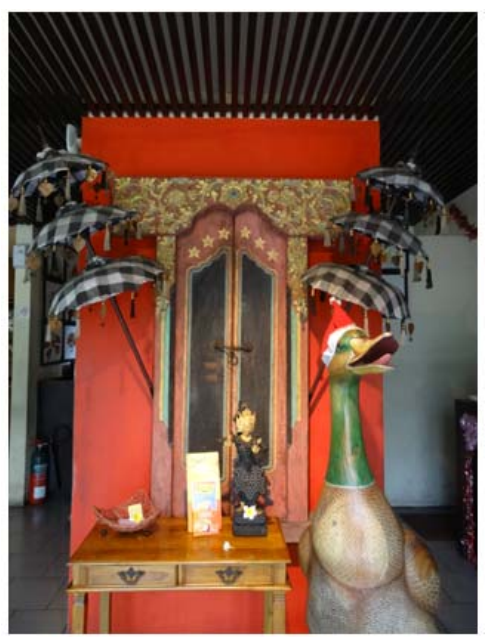

Gambar 30 Area Foyer restoran the Ubud

(Sumber: Polni, 2013)

Gambar diatas adalah satu satunya penerapan ornamen Bali pada restoran the Ubud ini. Dengan harapan dapat membawa nuansa ke-Bali-an, dibuatlah sebuah backdrop dengan gambar pintu bali yang diberi ukiran sulur sulur tumbuhan sesuai dengan konsep ke-patra-an dalam ragam hias Bali. Warna yang digunakan adalah warna khas Bali yakni merah dan warna prada atau warna keemasan. Kemudian tidak ketinggalan sepasang payung umbul dengan balutan kain poleng dipajang di kiri kanan pintu. Tidak banyak yang ditampilkan pada area ini, selain sebuah patung bebek yang cukup besar sebagai ikon dari restoran dengan latar belakang gambar pintu bergaya Bali.

\section{SIMPULAN}

Ragam hias Bali merupakan warisan budaya yang perlu dilestarikan di Indonesia. Motif dan warna yang ada pada ragam hias Bali mengandung makna simbolis yang erat kaitannya dengan kepercayaan masyarakat Bali sehingga dalam penerapannya ragam hias tersebut memiliki aturan dan perhatian khusus. Hal ini merupakan batasan bagi pengaplikasian elemen-elemen interior (lantai, dinding, langit-langit dan furnitur) agar tidak menyalahi aturan yang ada dan makna yang terkandung dalam masing-masing ragam hias tersebut.

Public space merupakan salah satu perencanaan ruang umum yang banyak melibatkan manusia sebagai pengguna ruang. Dalam hal ini latar belakang pengguna ruang public space sangat beragam diantaranya dari segi budaya, ekonomi, pendidikan, dll. Penerapan ragam hias Bali pada public space dalam hal ini Restoran Jimbaran dan The Ubud - Bebek Bengil di Jakarta merupakan salah satu contoh pengaplikasian ragam hias Bali yang sudah mengalami modifikasi sehingga tampil modern. Saat ini di Bali pun, sudah mengalami pergeseran arti ragam hias yang awalnya memiliki simbol kemewahan menjadi simbol ornamen dekoratif semata.

Diharapkan penelitian ini dapat memperkaya wawasan pembaca dalam memahami ragam hias Bali yang diterapkan pada public space. Sehingga kedepannya warisan budaya Indonesia dapat 
disajikan dengan baik sesuai dengan makna dan kaedah yang ada. Besar harapan warisan budaya Bali ini dalam hal ragam hias terutama yang difokuskan pada bagian pintu dapat dikenal luas oleh masyarakat Indonesia pada khususnya dan masyarakat dunia pada umumnya.

\section{DAFTAR PUSTAKA}

Arsitektur Rumah Bali. (30 November 2013). Diakses dari http://www.baliarchitectures.com/2009/06/arsitektur-rumah-bali/

Balika Ika, W. (2007). Jurnal Ilmiah Warna: Perkembangan Estetika Kori Kuwadi. Denpasar: Fakultas Seni Rupa dan Desain ISI Denpasar.

Davison, J., Enu, N., dan Granquist, B. (2003). Bali Architecture. Hongkong: Periplus Edition Ltd.

Fardon, R. (2006). Lela in Bali: History Through Ceremony in Cameroon. United States: Berghahn Books.

Fox, R. Critical Reflections on Religion and Media in Contemporary Bali. Netherlands: Koninklijke Brill NV.

Ragam Hias Arsitektur Tradisional Bali. (11 Februari 2012). Diakses dari http://www.scribd.com/doc/49238482/Ragam-Hias-Arsitektur-Tradisional-Bali

Ragam Hias Dalam Rumah Adan Bali. (11 Februari 2012). Diakses dari http://www.neraca.co.id/2011/11/16/ragam-hias-dalam-rumah-adat-bali/

Sadha, W. dan Couteau, J. (2005). Bali Today: Modernity. Jakarta: Kepustakaan Populer Gramedia.

Wijaya, M. (2002). Architecture of Bali: A Source Book of Traditional and Modern Form. Bali: Wijaya Words. 